\title{
Demons of Transitional Democracies: Politics of Insults and Acrimony in Ghana
}

\author{
Kwame Asamoah \\ Department of Public Administration and Health Services Management \\ University of Ghana Business School \\ P. O. Box LG 78, Legon, Accra
}

Tel: 233-268-228-475 E-mail: kasamoah@ug.edu.gh

Emmanuel Yeboah-Assiamah

Department of Public Administration and Health Services Management

University of Ghana Business School

P. O. Box LG 78, Legon, Accra

Tel: 233-542-038-794 E-mail: yimmanuel@yahoo.com

\begin{abstract}
Alex Osei-Kojo
Department of Public Administration and Health Services Management

University of Ghana Business School

P. O. Box LG 78, Legon, Accra
\end{abstract}

Tel: 233-020-900-9297 E-mail: oseikojo.alex@gmail.com

Received: September 8, 2013 Accepted: November 15, 2013 Published: December 11, 2013

doi:10.5296/jsss.v1i1.4725 URL: http://dx.doi.org/10.5296/jsss.v1i1.4725

\begin{abstract}
There is a general perception that Ghana has achieved remarkable success in democratic consolidation by conducting six general elections in the Fourth Republic without widespread violence since 1992. Yet, the kind of tensions and acrimony that surround her elections are
\end{abstract}




\section{Macrothink}

issues that cannot be glossed over. The 1992 Constitution of the Republic of Ghana paved the way for free speech and expression, which has been strengthened by the repeal of the Criminal Libel Law. Most political actors tend to abuse the freedom of speech enshrined in the Constitution by using abusive words and insulting their political opponents especially on the airwaves and during political campaigns. The persistent use of intemperate language affects the quality of policy discourse and also creates tension at every election year. Faced with the use of indecorous language at every election year, a common feature of elections in Ghana is the numerous appeals for peace from all sections of society. The use of indecent words by political actors thus poses a serious threat to Ghana's democratic dispensation as it can escalate into serious conflict with social, political and economic ramifications. This article examines how the use of indecent language can be detrimental to the developmental agenda of the country. The paper adopts content analysis to examine some of the statements by some key stakeholders during the 2012 general elections. A major finding of the study is that there is excessive use of abusive words on airwaves and political campaigns. Another finding of the study is that election periods in Ghana is characterized by clarion calls for peace and calming down tensions. The article recommends that key political actors must set practical leadership example, for their supporters to emulate by using decorous words before, during and after each election.

Keywords: Politics, Democracy, Acrimony, Elections, Demons, Democratic Consolidation 


\section{Introduction}

Politics is about power to make authoritative decisions, and these decisions are reached through careful deliberation and reconciliation of diverse views to reach consensus and compromise. In a democracy, one critical decision is the selection of political leaders. The process of selecting leaders is consistent with the deliberative conception of democracy, which involves open discussion with the potential of leading to an agreed judgement on policy (Miller, 1992). The deliberative conception includes elements of argument, in which individuals work to build support for their own position while simultaneously undermining support for an opponent's position (Schiffrin, 1985). Thus, within a democratic practice, arguments are unavoidable as individuals and groups discuss policy issues and decide on those who will assume political leadership. But while public discourse in a democracy is expected to be decorous, it seems that the environment that surrounds public debate in transitional democracies, like Ghana, is excessively aggressive and acrimonious. It is becoming increasingly clear that political actors tend to resort to the use of insults and abusive language to win political debate.

The political atmosphere of transitional democracies appears to be tensed with hot exchanges and abuse of language especially in the run up to general elections. It is believed that such a posture by key players within the political space during elections falls within the purview of the concept of argument culture, which is defined as a set of values, attitudes or beliefs which lead individuals to approach public discourse in terms of war-like interactions (Tannen, 1998). Ghana is not an exception to this high tensed-atmosphere prior to general elections in terms of the use of abusive, inciting and disgraceful rhetoric. It is obvious that political actors in Ghana resort to such negative approaches during political discussions with the aim of winning such debates which may probably contribute to one's political success. Ansolabehere and Shanto (1995) hold the view that winning such political debates may be to the advantage to the winner and work to the disadvantage of political opponents as they tend to lower the opponent's acceptance by the general voting public.

Within the context of this study, political actors who indulge in insults, abusive language, inciting comments are referred to as political "demons" as their acts have the potential to derail the democratic gains Ghana has made and create instability within the political system. These "demons" through their utterances and actions can plunge an otherwise a peaceful country into mayhem. The actions of these "demons" have been a serious concern to most eminent Ghanaians. Speaking at the Annual Democracy Lecture of 2013 organized by the National Commission for Civic Education (NCCE), the Ashanti King, Otumfuo Osei Tutu II, expressed a serious concern that the social fabric of the Ghanaian society has been so polarized with politics which he referred to as "demons eating away the gains of democracy under the Fourth Republic" (Daily Graphic, $18^{\text {th }}$ May, 2013 p. 1). He further pointed out that "the air we breathe is polluted with party propaganda and there is no issue that is not politicized" (ibid). This assertion was made to explain the polarization of the Ghanaian society due to partisan politics.

Recent developments in Ghanaian politics point to the fact that elections continue to be 
characterized by insults and palpable use of abusive language. Kurtz (1996) argues that the talk show culture opens political debate to multiple views, which tend to exist on the periphery resulting in general impoverishment of the political culture and makes it difficult in achieving consensus on difficult political issues. Consequently, most citizens expect that the use of intemperate language needs to be nipped in the bud. The charged atmosphere at every election year necessitates numerous appeals by civil society organizations, eminent citizens and the clergy to major political actors to be responsible in terms of language used at political platforms and on radio and television discussions. Instead of devoting attention to developmental issues like poverty reduction, job creation, and improvement in the health facilities for the people after a party wins an election, the attention now turns to how to maintain peace after an election. The major point here is that development cannot thrive in an unstable political environment and efforts must be made to ensure tranquility in the country before, during and after each election.

\section{Methodology}

The overarching objective of this study is to critically analyze the phenomenon of indecent and abusive language in Ghanaian politics. The study analyzes specific statements by some key Ghanaian political actors especially in the run up to the 2012 general elections. Based on this objective, the study is situated in the qualitative paradigm of social research. The qualitative paradigm allows a researcher to obtain data 'in the form of impressions, words, sentences, photos, symbols, and so forth' (Neuman, 2007, p. 85). The paper uses retrospective literature analysis of secondary data; mainly scholarly journals, books and newspaper publications. The paper ensured compliance with ethical standards in social research by ensuring that all citations used were duly referenced.

\section{Literature Review}

\subsection{The Concept of Politics}

The fundamental goal of any political activity is to provide structures and processes through which rival groups and ideas would compete over means and ends, priorities and differences (Bluwey, 2002). This definition suggests that the concept of politics is an avenue for discussing and reconciling views to reach a decision that broadly satisfies the national interest. The definition acknowledges that there will be opposing views yet that should not drive actors or participants into choosing abusive language or to conduct themselves in a manner which is likely to be detrimental to democracy and peace. It can be inferred from the definition that politics is about how to reach a compromise or consensus; it is about how best conflicts or disagreements are settled amicably devoid of excesses. In order to achieve this, public discourse must be underpinned by a set of basic moral principles (Berkowitz, 1996). Kochman (1984) points out that the distinctive protocols on public discourse must involve all sides to the issue and actors must remain rational; one side should seek to avoid actions or statements that others find offensive; there is no monopoly of truth; flexibility is paramount; and strong self assertion is to be avoided.

Politics, ideally, is to achieve a well- ordered society; for without it, life is not worth living; 
this point has been made that "in the pursuit of goals -individual and collective- men devise rules and procedures for superordination and subordination ... they encounter and create power, authority and rulership" (Dahl and Jourvenel, 1970). Politics is the means through which society collectively synchronizes ideas, deliberates on issues, manages conflicts and reaches consensus on how best resources should be allocated. Political activities involve the processes of selecting leaders to make authoritative decisions and in these processes or activities, the conduct of political actors and supporters need to be guided, guarded and be circumspect in speech, actions and inactions. The ability of a nation or people to engage in a civil discussion and selection of their leaders without hostility, acrimony and insults determines their level of political maturity.

Politics, though some have abused it and do understand it in derogatory terms, the concept classically is concerned with the best way through which leaders are selected to make authoritative allocation of resources; it involves the relationship of power, rule or authority and the various means by which a state or political system discusses or deliberates on issues of national interest (Easton, 1953; Weber, 1965; Magstadt \& Schotten, 1996).

\subsection{Concept of Democracy}

In spite of the controversies surrounding the appropriateness and viability of democracy in Africa, Nzongola-Ntalaja (1997) maintained that Africa is a storehouse of human and cultural values that appear quite compatible with the very tenets of democracy as a political concept. He argued that such African values have been undermined and therefore remained stunted in their development by both colonial rule and post-colonial misrule. Democracy has been conceptualized as a moral imperative; a social process and political practice. Democracy as a moral imperative suggests that it is a necessity and a sine qua non for a just and better society. Democracy as a process means it is a continuous process of enhancing equal access to fundamental human rights and civil liberties for all (Nzongola-Ntalaja, 1997).

Public discourse, which involves arguments and discussions in a democratic governance is seen as a social process and it is never complete or perfect but must strive for perfection. Therefore, in spite of the successes gained by Ghana in terms of conducting six successful general elections in the Fourth Republic, there is the urgent need to constantly streamline her democratic practices to make it more relevant to meet contemporary aspirations of the people. It is imperative to work towards achieving a society where the acrimony surrounding election periods would be a thing of the past. There is the need to achieve a democracy where it will be uncommon to hear opinion leaders always begging for peace and calming down tensions in electoral season due to insults on one's political opponents by "demons." Van Eemeren, Grootendorst, Jackson, and Jacobs (1993) propose a model of a 'perfect' discourse which includes: identifying disagreements; establishing agreement as the process by which arguments are to proceed; providing for indefinite exploration of relevant issues; ending in resolution which satisfies all participants. In order to ensure sanity in public discourse, these ideals must be adhered to by all key stakeholders in the political process so as to consolidate the democratic gains that Ghana has chalked so far. 
Chapter Five (5) of the 1992 Constitution of Ghana adequately guarantees the fundamental human rights and freedom of its citizens. Article 21(1a) provides that "all persons shall have the right to freedom of speech and expression, which shall include freedom of the press and other media." In 2001, the Government of Ghana repealed the Criminal Libel Law in order to encourage free speech and expression. The government's memorandum on the bill issued to the then Attorney General and Ministry of Justice was indicative of the government's commitment to democratic consolidation in Ghana. The memorandum further stated that such criminal codes were colonial creations to frustrate free speech of Ghanaians and it was long overdue to be removed from the country's legal documents.

Repealing the Criminal Libel Law was meant to encourage a free and congenial expression of thoughts and opinions which in the long run would encourage "more speech". Coleman and Alger (1996) have observed that the concept of "more speech" came up to counter the notion that some ideas should be suppressed because they stigmatize certain groups or individuals. Their argument is that society ought to devise mechanisms to support marginalized individuals and groups while maintaining other people's right to free speech. This same point has been emphasized by O'Neil (2004) that "societies, institutions and individuals can exercise their own free speech rights to disagree with or denounce attitudes or comments perceived to be objectionable".

The repeal of the Criminal Libel Law in Ghana was to enhance free speech but it appears it has rather encouraged "uncouth free speech" by "demons" which has become problematic to Ghana's democracy especially in election years. However, like an athlete, a man of virtue needs not to only flex his civic muscles from time to time but needs to maintain a greater sense of discipline, austerity and self-denial (Kahn, 1961). Inferring from Kahn's statement, it could be suggested that in spite of the freedoms enshrined by the 1992 Constitution and repeal of the Criminal Libel Law, citizens need not flex their civic muscles any how or unduly but need to be self-disciplined and mindful of their speech during deliberations. Thus, the structure of deliberation is motivated by a principle of deliberative inclusion, which suggests that those who participate in political discussions must work to find politically acceptable reasons for others to accept their position (Cohen, 1998).

Various scholars have argued that the nature of the political system generates the kind of political culture; therefore, differently constructed political regimes generate different political behaviors and attitudes (Thiele, 2003). Thiele (2007) traced the role of legislators in ancient Greece to involve the creation and maintenance of the city-state effectively in a manner that encouraged the ordering of behavior and souls of the citizenry (ibid). The Greeks had a form of education known as "padeia" which was meant to shape the virtues, souls and characters of the citizenry. Therefore, political philosophers such as Plato and Aristotle have maintained that education forms a greater portion of the legislator's task. For instance, Plato suggests that "the responsibility for a people's wickedness lay not with the people themselves but with the politicians responsible for their education and government" (Thiele 2007, p. 156). Plato further argues that, "the planters are to blame rather than the plants" (cited in ibid). Plato suggests that political leaders need to lead the way and to demonstrate exemplary leadership worthy of emulation. 
It, therefore, becomes disturbing when political leaders, Ministers of State, members of Parliament or government spokespersons act as "demons" when they use offensive language against their opponents. Such attitudes have a cascading effect on their supporters known in local parlance as "foot-soldiers" who are encouraged to use similar posture to defend their leaders. Again, the institutions of state such as the National Commission for Civic Education (NCCE) among others are not doing enough to propagate a spirit of virtue and patriotism in the minds of the citizens.

Aristotle in "Politics" attempted to make a distinction between the 'Good Man' and the 'Good Citizen'. He concluded that it is possible to be a good citizen without necessarily being a good man and that the excellence of the good citizen is relative to the constitution. However, the good man is the one who is virtuous and more circumspect in his ways. This classification suggests that there are two groups of citizens: those who hide behind the constitution, legal technicalities and the law to perpetrate vice, which includes the use of vitriolic languagesuch people are the "demons"; there is also another category of citizens who are virtuous, whether there are laws or no laws will not take undue advantage of legal laxities to perpetrate uncouth media discussion in society.

Arguing on the relationship between man and the 'polis', Aristotle argued that a man whose character is perfected becomes the best of animals but without law and justice man becomes the worst and most miserable. He argued that "man is furnished from birth with arms which are intended to serve the purposes of moral prudence and virtue but this may be used in preference for opposite ends. ... if he be without virtue, he is a most unholy and savage being, and worse than all others in the indulgence of lust and gluttony" (Cited in Cohen and Fermon, 1996 p. 110).

\subsection{Political Tolerance}

In order to ensure sanity in Ghana's political discourse, there is a need for players who engage in political discussions to be tolerant of the views of one another, so that the business of nation building can be focused on. Sullivan, Piereson and Marcus (1982, p. 76) write that "political tolerance exists when respondents allow the full legal rights of citizenship to groups they themselves dislike...intolerance exists whenever respondents object strongly to a group or its ideas, and refuse that group the rights of participation in the political process." Nie, Junn and Stehlik-Barry (1996, p. 29) offer a similar perspective that "tolerance is the belief that all citizens have the right to express their political views, regardless of how dangerous or repugnant those views may be." If tolerance means that all citizens have the right to express their views, then the denial of such a right constitutes intolerance. Consistent with this position, Sniderman et al. (1989, p. 42) suggest "it is intolerant to refuse to accept as legitimate a group merely because its ideas are different."

The need for political tolerance is linked to the broad-based value shift ongoing in advanced industrial societies (Golembiewski, 1995). Langerak (1994) suggests that a notion of tolerance is needed as it allows individuals to respect the views of others. But it must be emphasized that tolerance in political discourse can only be achieved through the enforcement of punitive measures that will deter others from engaging in abusive language. 
Chong (1994) argues that tolerance does not arise from people's unwillingness to be restrained in public discourse; thus, there must be punitive measures against those who exhibit unruly behavior in public discourse. Such punitive measures must be combined with other background conditions including: basic liberty, basic opportunity, and fair opportunity to create a decent deliberative atmosphere. (Gutmann \& Thompson, 1996).

One important way of achieving political tolerance is education. First there is need for extensive education for the general public of the potential ills of intemperate language in Ghana's political discourse. Golembiewski (1995) believes that higher education is shown to have strong positive correlation with greater tolerance; the reason is that higher education leads the individual to value priorities that are conducive to greater openness and political diversity. Nie, Junn and Stehlik-Barry (1996) affirm the role of education in enhancing tolerance by pointing out that education has strong positive influence on political knowledge, political participation and voting, attentiveness to politics and tolerance. The implication of this for a decent political discourse in Ghana is that civic institutions such as the National Commission for Civic Education (NCCE) must intensify efforts in public education. It is important for the NCCE to regularly educate the citizens on the need for political tolerance.

\section{Discussion and Analysis: Run up to the 2012 General Elections}

This section assesses the aftermath of comments that were recorded during the 2012 general elections, which caught the attention of the media and various stakeholders. This section refrains from value-judging the comments but focuses on the appeals and calls by opinion leaders and civil society organizations for people to desist from such insults, war-mongering posture among others.

It is instructive to note that promoting a culture of political tolerance is a constitutional requirement. Chapter six (6) of the 1992 Constitution of Ghana implores the state to inculcate into its citizens a spirit of healthy political discourse. This provision is forcefully brought home by Article 35(9) which states that "the state shall promote among the people of Ghana the culture of political tolerance."

The 'winner-takes-all' semblance of Ghana's politics appears to make general election periods very tensed and the atmosphere becomes so charged, which some individuals have asked for its revision (Sarpong, Daily Graphic, $15^{\text {th }}$ June p. 17). The two main political parties in Ghana: the National Democratic Congress (NDC) and the New Patriotic Party (NPP), which have similar support base, are usually victims of indecent language. Noting the way politicians were psyching their supporters up, the presidential candidate of the Convention People's Party (CPP) for 2012 election, Dr. Abu Sakara, cautioned that: "no one is worth dying for; do not fight for any political party and we should not even fight over the outcome of the elections" (Daily Graphic, $3^{\text {rd }}$ July, 2012). This comment suggests that political leaders and followers were engaged in a 'cold war' which was evidenced by threats or preparedness of some supporters to die for the sake of the elections and for their political parties.

At the launch of the second national peace walk, the Chairman of the National Peace Council, 
Rev. Prof. Emmanuel K. Asante posited that: "let feuding parties of our nation learn to enter into dialogue and negotiate with one another, bearing in mind that no dispute or rancor is so ingrained that talking and arriving at a compromise cannot settle." He further cautioned that: "indeed, we must understand that there is more wickedness in refusing to reconcile than in fighting; no party in the quarrel should think that he has any advantage by continuing the state of hostility because very often the outcome of such hostility is not certain" (Daily Graphic, $3^{\text {rd }}$ July, 2012 p. 17).

At the $18^{\text {th }}$ Annual National Ramadan, the late former Vice-President of Ghana, Alhaji Aliu Mahama, stated that: "as Muslim leaders, we should not sit down and watch some selfish politicians to soil the image of Islam by using our youth to create confusion and violence in the name of partisan politics"(Daily Graphic, $26^{\text {th }}$ June, 2012). It appears that all those who mounted the platform on that occasion used substantial time to stress on the need to calm down and use temperate language. Giving his maiden sermon as the $3^{\text {rd }}$ Catholic Archbishop of Kumasi, Most Rev. Anokye used the platform to cool tempers that have risen in the political atmosphere. He put it out succinctly that "we can see a peaceful, secure and stable country when the media boldly denounces and cuts off people who shamefully abuse, insult, curse and inflame passions on the airwaves" (Daily Graphic, $16^{\text {th }}$ July 2012, p.32).

The Archbishop Duncan-Williams of the Christian Action Faith Ministries also cautioned political practitioners to work towards peace and not just professing it. He further cautioned both politicians and citizenry that: "those who allow themselves to perpetuate, be instruments or vehicles of violence for money or recognition would wake up on the wrong side of history". He further strongly posited that "anyone who does not want a curse on their family from the cry of innocent blood must be cautious of their actions and whatever they say, now, during and after December 7, 2012" ( Daily Graphic, $10^{\text {th }}$ July 2012, p. 19).

Akordor (2012) observing the various appeals from all sections of the society posited that: "today our ears are deafened in a cacophony of appeals for a peaceful election; why should an election of Members of Parliament and a president to lead this country to progress become a battle-cry such that everybody should be on his/her knee begging for peace?" (Cited in Daily Graphic, $17^{\text {th }}$ July 2012, p. 7).

Speaking at the Freedom Power Lectures organized by Centre for Freedom and Accuracy, Emeritus Bishop Peter Kwasi Sarpong used the platform to advise communicators of the two main political parties, the National Democratic Congress and the New Patriotic Party (Daily Graphic, June $15^{\text {th }} 2012$, p. 17). This was during the period when the political atmosphere was very charged, with the air waves were full of insults, acrimony and hostile pronouncements.

Political actors and their followers have abused the freedoms guaranteed by the 1992 Constitution and repeal of the Criminal Libel Law; the abuse of freedoms and rights in the run up to 2012 general elections became worrisome. Several civil society organizations raised red flags on the use of acrimonious language on the air waves by "demons." For instance, at the launch of the 2012 Human Rights Report in Accra, the Director of Amnesty International (Ghana Chapter) used that platform to caution politicians and the general public that such 
emerging negative and acrimonious tendencies could spell doom for the country's democracy and could be detrimental to the gains made in democratic consolidation (Daily Graphic, $18^{\text {th }}$ June 2012, p. 19).

From the discussion above, the clarion calls for peace by all stakeholders- religious bodies or civil society organizations- is an indication of the context of elections in Ghana. Election is simply a mechanism for selecting leaders and ideally must not elicit clarion calls by all and sundry for peace. The content of the appeals and clarion calls above do clearly show the kind of atmosphere that existed during such political seasons. It can be asserted that even though these comments give a hint of how intemperate language by the "demons" poison the atmosphere, the appeals by a section of opinion leaders in politics and religion in "saved" the country from being plunged into mayhem. These findings are consistent with suggestions by Golembiewski (1995) and Nie, Junn and Stehlik-Barry (1996) that education and tolerance have a positive relationship.

\section{Conclusion and Recommendations}

Ghana has chalked much success in consolidating her relatively young democracy through the conduct of peaceful elections. In spite of the peaceful nature of the elections, there appears to be acrimony, hate speech and much hostility between political actors perpetrated by "demons." The use of unguided, intemperate and uncouth language in the media and other platforms during these seasons make the whole exercise of elections acrimonious. What is paradoxical is that such acrimonious language comes from top ruling party and opposition members who aspire to be leaders of the country.

The discussion above suggests that the character of a political system, state institutions and political actors have much to do when it comes to sustaining healthy politics. Political leaders or elites are to institute appropriate mechanisms to enhance or trickle down virtue through the rank and file of their supporters; and all agents of the party who speak on their behalf are to be bound by them. It should not be done with mischief or pretense; they are to genuinely institute such mechanisms and to reward individuals who abide by them. In the end, the ultimate responsibility for any individual or spokesperson of a political party who engages in unhealthy comment or media discussion must be borne by the political party unless they condemn the statement or bring that person to book.

The phenomenon of politicizing everything and the use of insults against political opponents by these "demons" is against the letter and spirit of democratic governance. It sounds paradoxical that liberal democracy under the Fourth Republic instituted by the 1992 Constitution and further enhanced by the repeal of the Criminal Libel Law has made it possible for the air waves to be abused as platforms for spewing venoms. The current trend is an affront to national development and that national goals are more likely to be perverted by politics. Despite Ghana's success in organizing peaceful elections, it is of much importance to move a step ahead by making real sense of the concept of politics; the use of intemperate language which raises tensions and acrimony during elections need not be part of the Ghanaian political system. Election period must not be dominated by clarion calls for peace and 'no war' if indeed all actors play their roles responsibly. It is recommended that the 
NCCE, civil society organizations, religious bodies, and chieftaincy institutions must play a robust role in educating all the political players about the importance of using decent language on political campaign platforms and discussions on radio and television stations. Available evidence shows that education has a strong positive influence on political knowledge, political participation and voting, attentiveness to politics and tolerance (Nie, Junn, \& Stehlik-Barry, 1996). Besides, political parties must be courageous enough to sanction their members who engage in acrimonious debates, vitriolic attacks on opponents and usage of indecorous language in political discourse.

\section{References}

Ansolabehere, S., \& Iyengar, S. (1995). Going negative: How attack ads shrink and polarize the electorate. New York: The Free Press.

Berkowitz, P. (1996). The debating society. The New Republic, 215, (November, 25), 36-42.

Bluwey, G. K. (2002). Political science: An introduction. Yamens Press Ltd: Accra

Chong, D. (1994). Tolerance and social adjustment to new norms and practices. Political Behaviour, 16, 21-53. http://dx.doi.org/10.1007/BF01541641

Cohen, M., \& Fermon, N. (1996). Princeton Readings in Political Thought: Essential Texts since Plato. Princeton, NJ: USA, University Press.

Cohen, J. (1998). Democracy and liberty. In J. Elster (Ed.), Deliberative Democracy (pp. 185-360). Cambridge: Cambridge University Press. http://dx.doi.org/10.1353/jod.1998.0004

Coleman, A. L., \& Alger, J. R. (1996). Beyond speech codes: Harmonizing rights of free speech And freedom from discrimination on university campuses. Journal of College and University Law, 23, 91-132.

Daily Graphic. (2013). "National goal perverted by politics.” Saturday, $18^{\text {th }}$ May, 2013, p. 1.

Daily Graphic. (2012). "Do not die for politicians.” Tuesday, $3^{\text {rd }}$ July, 2012, p. 1.

Daily Graphic. (2012). "Politicians must strive for integrity.” Friday, $15^{\text {th }}$ June, 2012, p. 17.

Daily Graphic. (2012).“Aliu Mahama advises Muslims to avoid lawlessness” Tuesday, $26^{\text {th }}$ June, 2012,

Daily Graphic. (2012). “Ghanaians must learn to be tolerant.” Monday, July $16^{\text {th }}$, 2012, p. 32.

Daily Graphic. (2012). “Ghanaians must work for peace” Tuesday, July 10" , 2012, p. 19.

Daily Graphic. (2012). "Politics of acrimony” Tuesday, July 17, 2012, p. 7.

Daily Graphic. (2012). “Amnesty International raises red flags on violence” Monday, June $18^{\text {th }}, 2012$.

Dahl, R., \& Jourvenel, B. D. (1970). The nature of politics. In B. D. Bell., K. W. Deutsch., \& S. M. Lipset (Eds,). Issues in Politics and Government. New York: Hughton Mufflin. 
Easton, D. (1953). The Political system. New York: Knopf.

Golebiowska, E. (1995). Individual value priorities, education and political tolerance. Political Behaviour, 17, 23-48. http://dx.doi.org/10.1007/BF01498783

Gutmann, A., \& Thompson, D. (1996). Democracy and disagreement. Cambridge: The Belknap Press of Harvard University Press.

Kahn, E. (1961). The Predicament of democratic man. NY: Macmillan.

Kochman, T. (1984). The politics of politeness: Social warrants in mainstream American public etiquette. In D. Schiffrin (Ed.), Meaning, form, and use in context: Linguistic applications (pp. 200-209). Washington, DC: Georgetown University Press.

Kurtz, H. (1996). Hot air: All talk all the time. New York: Random House

Langerak, E. (1994). Pluralism, tolerance and disagreement. Rhetorical Quarterly, 24, 95-106. http://dx.doi.org/10.1080/02773949409391008

Magstadt, T. M., \& Schotten, P. M. (1996). Understanding politics: Ideas, institutions and issues. (4th ed). St. Martins Press. USA

Miller, D. (1992). Deliberative democracy and social choice. Political Studies, 40, 54-67. http://dx.doi.org/10.1111/j.1467-9248.1992.tb01812.x

Neuman, W. L. (2007). Basics of social science research: Qualitative and quantitative approaches. Boston: Pearson Education.

Ngongola-Ntalaa, G. (1997). The state and democracy in Africa. In G. Nzongola-Ntalaa \& M. C. Lee (Eds.), The state and democracy in Africa. Harare: African Association of Political Science.

Nie, N., Junn, J., \& Stehlik-Barry, K. (1996). Education and Democratic Citizenship in America. Chicago: The University of Chicago Press.

O'neil, P. (2004). Publishing the unpalatable. In Bruneau \& Turk (Eds.), Disciplining dissent: The curbing of free expression in academia and the media. Ontario: James Lorimer and Company Publishers Ltd.

Schiffrin, D. (1985). Everyday argument: The organization of diversity in talk. In T. van Dijk (Ed.), Handbook of discourse analysis: Discourse and dialogue (pp. 35-46). London: Academic Press.

Sniderman, Paul, M., Tetlock, Philip, E., Glaser, James, M., Green, Donald Philip, \& Hout, Michael. (1989). Principled tolerance and the American mass public. British Journal of Political Science, 19, 25-45. http://dx.doi.org/10.1017/S0007123400005305.

Sullivan, John, L., Piereson, James, \& Marcus, George, E. (1982). Political Tolerance and American Democracy. Chicago: University of Chicago Press.

Tannen, D. (1998). The argument culture: Moving from debate to dialogue. New York: 
Random House.

The 1992 Constitution of Ghana. Accra: Ghana.

Thiele, L. P. (2003). Thinking Politics: perspectives in ancient, modern and postmodern political Theory. (2nd ed.), Chatham House Publishers.

Van Eemeren, F., Grootendorst, R., Jackson, S., \& J, S. (1993). Reconstructing argumentative discourse. Tuscaloosa, AL: The University of Alabama.

Weber, M. (1965). Politics as a vocation. Philadelphia: Fortress Press.

\section{Copyright Disclaimer}

Copyright reserved by the author(s).

This article is an open-access article distributed under the terms and conditions of the Creative Commons Attribution license (http://creativecommons.org/licenses/by/3.0/). 